\title{
Ecology of Fescue Grasslands in Glacier National Park
}

\author{
ROBIN W. TYSER \\ Department of Biology and Microbiology ^ University of Wisconsin-LaCrosse \\ LACROSSE
}

Fescue grasslands are important habitat types within several drainage systems in Glacier National Park. A two year field study $(1989,1990)$ was undertaken to assess factors potentially threatening the integrity of these grasslands. Objectives of this study are to:

1. Identify factors determining the distribution of fescue grasslands;

2. Describe plant and vertebrate communities inhabiting fescue grasslands;

3. Identify factors that are potentially disruptive to the natural integrity of fescue grasslands; and

4. Develop a management model that includes hypotheses to be tested by management actions.

Field work for both first and second seasons has now been completed and data analysis is in progress.

\section{$\downarrow$ MethodS}

Glacier's computerized Geographical Information System was used to determine general elevation and slope limits of fescue grasslands and coverage of these grasslands within specific drainages. Size-specific mortality comparisons of trees in burned versus unburned ecotone areas in the North Fork grasslands were used to assess the role of fire in preventing tree encroachment into grasslands.
In each of 11 grassland study sites, the presence of all vascular plant species, excluding Carex spp., was determine in $25-50$ quadrats $\left(0.1 \mathrm{~m}^{2}\right)$ placed along a $100 \mathrm{~m}$ transect. Species frequency and richness were determined for each site. Sites were adjacent to primary roads (4 sites), secondary roads (4 sites), and back country trails ( 3 sites). In 6 other sites, each of which was approximately 20 ha in size, vertebrate populations were censused using a $400 \mathrm{~m}$ trap line of Sherman live traps (small mamma's), the "consecutive flush" method (birds), burrow densities in $10 \times 100$ belt transects (ground squirrels and badgers), surface coverage of elk pellets, and a limited number of pitfall traps (amphibians and reptiles). Trapping was repeated twice each summer (late June/early July and late August).

Possible impacts of transportation routes and underground utility line construction were assessed using two quadrat-based vegetation parameters (native species richness, exotic species richness). Native plant species richness was also estimated in stands dominated by common timothy, spotted knapweed, and native fescues.

\section{$\downarrow \quad$ Preliminary Results}

Field observations and GIS Landsat data indicate that fescue grasslands occur largely at elevations below $1620 \mathrm{~m}$ and on alluvial deposits. Extensive fescue grasslands occur on both eastern and western slopes of the Continental Divide. Grassland coverage ranged 
from $0.3 \%$ to $3.2 \%$ in the drainage systems examined. The 1988 Red Bench fire resulted in nearly $100 \%$ mortality of lodgepole pines in the smallest size class occurring in the forest/grassland ecotone, suggesting that fire effectively discourages encroachment of lodgepole pine into grasslands.

Idaho fescue (Festuca idahoensis) and/or rough fescue $(F$. scabrella) were among the three most common grasses at all 11 study sites. Other common nonfescue grasses occurring in one or more sites included Richardson's stipa (Stipa richardsonii), oatgrass (Danthonia intermedia), junegrass (Koeleria cristata), wheatgrass (Agropyron caninum), and common timothy (Phleum pratense). Common forbs include yarrow (Achillea millefolium), northern bedstraw (Galium boreale), field chickweed (Cerastium arvense), and silky lupine (Lupinus sericeus). Among-site variation in vegetation patterns likely results from a combination of factors, including variation in substrate characteristics, precipitation, fire frequency, historical plant dispersal patterns, andmore recently_ human impact.

Nine bird species were observed within grassland vegetation, though vesper sparrows (Pooecetes gramineus) were the only common resident species. Three species of small mammals were trapped (Peromyscus maniculatus, Zapus princeps, Microtus pennsylvanicus), with $P$. maniculatus being by far the most commonly trapped species. Trap success was higher in 1990 than in 1989. Spring precipitation levels in 1990 were unusually high and possibly resulted in higher resource levels and increased small mammal reproduction.

Exotic vegetation is likely the factor most disruptive to the park's fescue grasslands. One or more exotic species occurred at each of the eleven vegetation study sites, including the three backcountry trail sites. The two most widely distributed species were common timothy (Phleum pratense) and Kentucky bluegrass (Poa pratensis), both of which may have been intentionally seeded in roadside areas by park resource managers prior to 1980 and in backcountry areas by horse concession personnel in the 1930 's. In the St. Mary valley grasslands, the occurrence of common timothy and spotted knapweed was associated with substrate disturbed by post- 1980 underground utility line construction.

Estimates of four plant community parameters (coverage by native grasses, coverage by native forbs, diversity, and richness) in patches dominated either timothy, spotted knapweed, or native fescues were all lowest in the knapweed patch (Table 1). Except for forb coverage, these parameters were also lower in the timothy patch than in the fescue patch. Thus, both exotic species, but especially spotted knapweed, appear to negatively affect native fescue vegetation.

Table 1. Diversity, species richness, and native species cover from quadrats within spotted knapweed (Centaurea), common timothy (Phleum), and native fescue (Festuca) stands. For cover and richness data, back-transformed means of square root-transformed data are given, followed in parentheses by untransformed means of square root-transformed data are given, followed in parentheses by untransformed means and their standard errors. N=20, 40, and 40 quadrats for the (Centaurea, Phleum, and Festuca patches, respectively

Diversity Richness Graminoids Forbs

$\begin{array}{lcccc}\text { Centaurea } & 0.385 \pm 0.042 & 7.0(2.7 \pm 0.1) & 9.5(3.2 \pm 0.3) & 7.1(2.8 \pm 0.3) \\ \text { Phleum } & 0.872 \pm 0.028 & 12.7(3.6 \pm 0.1) & 17.6(4.3 \pm 0.2) & 52.3(7.2 \pm 0.3) \\ \mathrm{F}_{2,97} & 90.084 & 53.994 & 43.833 & 71.770 \\ \mathrm{p} & <0.001 & <0.001 & <0.001 & <0.001 \\ \text { Comparisons* } & \text { CenPhlFes } & \text { CenPhlFes } & \text { CenPhlFes } & \text { Cen Fes Phl }\end{array}$

*Patch acronyms $(\mathrm{Cen}=$ Centaurea, $\mathrm{Phl}=$ Phleum, $\mathrm{Fes}=\mathrm{Festuca})$ not connected by underlining have means differing significantly from one another $(\mathrm{p}<0.05$, Tukey multiple-comparison tests). 